Korovina L. D., Kryshtal V. Ye.

\title{
COMPLEX APPROACH TO REHABILITATION OF WOMEN WITH PARANOID SCHIZOPHRENIA
}

Kharkiv National Medical University, Ukraine

\begin{abstract}
The article shows the results of examination of 60 patients with cerebral stroke. The study implied the assessment of the development of somatogenic depressive disorders for one year. Acute phase of cerebral stroke was characterized by various disorders of consciousness which were further accompanied by cognitive impairments, and after disorders of consciousness disappeared patients developed various psycho-emotional disorders, predominantly somatogenic depression and anxiety. The proposed psychotherapeutic correction system has allowed to reduce the frequency and severity of this disorders and to improve quality of life and social functioning of post-stroke patients.
\end{abstract}

KeyWords: Somatogenic depression, anxiety, psychotherapy, cerebral stroke.

\section{INTRODUCTION}

Schizophrenia is one of the most important mental diseases and its average incidence is $1 \%$ of the population. The disease differs by a long-term duration, quite often it leads to the reduction or loss of physical capability, has essential social consequences. Disability of the people with schizophrenia constitutes $40 \%$ to $80 \%$ in different regions, which testifies to the high level of the patients desadaptation $[2,8,11,12,16]$.

The introduction of modern methods of schizophrenia treatment into the clinical practice, development and implementation of the new antipsychotic drugs, has essentially improved the treatment results due to the reduction of not only positive but also negative symptoms, and, in many cases, avoid the development of neuroleptic syndrome $[5,6,7,14]$.

\section{Corresponding Author:}

Liliia Korovina, MD, PhD, assistant professor of department of Psychiatry, Narcology and Medical Psychology Kharkiv National Medical University, Ukraine. E-mail: l-korovina@ukr.net
The rehabilitation of mentally disabled people is not limited to the elimination of psychopathologic symptoms and is aimed at the creation of the optimum social functioning conditions for them, improvement of the life quality, ability to the independent active life - nowadays this challenge is becoming even more pressing $[1,3,13,14,15$, 16 ].

Quick and successful integration of patients into the society, improvement of their psychophysical activity, development of relations with the people around, require complex approach to schizophrenia therapy, which includes the combination of psycho-pharmacotherapy, psychotherapy and psycho-educational trainings $[2,4,9,10,11]$.

\section{PURPOSES, SUBJECTS and METHODS:}

\subsection{Purpose}

The improvement of treatment efficiency and rehabilitation of patients with paranoid schizophrenia through implementation of the complex psycho-rehabilitation program based on the comparative (clinical and psychopathological, clinical and anamnestic, psycho-diagnostic) examination of the paranoid schizophrenia patients.

\subsection{Subjects \& Methods}

To achieve this goal, on condition of the informed consent following the principles of bioethics and deontology 
our study was conducted at Kharkiv Regional Clinical Mental Hospital No.3.

140 female patients aged 18-35 with the paranoid schizophrenia during the stabilization period were examined. The whole contingent was divided into two groups. The main group (group of study) constituted 94 patients. These patients received complex of treatment combined with the psychoeducational program developed on the basis of the results of our own research and psychopharmacological therapy. Another group (the control one) included 46 patients, who received the standard regulated therapy. In our research study, we used such methods: complex clinical and psychopathological, clinical and anamnestic, psychodiagnostic (psychometric questionnaires and scales) examination.

According to the examination results in the clinical hospital the examined patients predominantly suffered from the paranoid hallucinatory syndrome with the stable delusional and hallucinatory (including dialogues) syndromes. Besides, $8 \%$ of the patients were found to have signs of oneiroid syndrome, in most cases of negative mystically-religional nature. The primary negative syndromes were manifested by the essential disorders in thinking and speech, severe ambivalence and autism. Disorders of social communication ability dominated among secondary negative disorders and some patients suffered from hypokinesia. Cognitive disorders were essential and were manifested by detraction, operative memory reduction, and inability of planning.

A complex approach, combining pharmacopeia and pshychoeducational program, was used for the improvement of life quality and re-adaptation of the patients.

In order to address the challenge adequately, we used the integrated model of the psycho-educational work, which included the use of diverse informational modules, approaches of the cognitive and behavioral pshychoterapy, training interactions (informational trainings, trainings of positive self-perception, trainings of the compliance improvement, trainings on formation the communicative abilities and skills, trainings of solving the interpersonal communication issues), problem-oriented discussions and family psychotherapy.

The modules of the psycho-educational program were based on the information concerning the reason, development, methods of correcting the unfavorable factors separately for the clinical peculiarities, life quality, resocialization, treatment satisfaction. Additionally, each module had the element of the cognitive and behavioral therapy, which was aimed at the reinforcement of the effect and reduction of the intervention period.

Before the beginning of the psycho-educational intervention the average composite score according to the PANSS positive scales in the main group amounted to $26.1 \pm 4.1 ; 26.4 \pm 4.1$ points in the control group; $6.7 \pm 1.5$ and $13.1 \pm 1.3$ points after therapy termination, correspondingly. The level of positive symptoms manifestation in the main group reduced by $71.3 \%$ and by $50.9 \%$ in the control group, correspondingly.

Before treatment the average complex score according to the negative PANSS scales in the key group amounted to $25.3 \pm 3.9 ; 25.4 \pm 4.2$ points in the control group; $7.6 \pm 1.1$ and $14.2 \pm 1.6$ points after the therapy termination, correspondingly. The level of negative symptoms presentation in the main group reduced by $67.1 \%$, and by $51.8 \%$ in the control group, correspondingly.

The average complex score according to general psycho-pathological disorders before treatment in the main group constituted $52.1 \pm 9.1 ; 52.3 \pm 9.0$ points in the control group; $17.7 \pm 2.9$ and $30.1 \pm 6.8$ points upon therapy termination, correspondingly. The level of general psychopathological symptoms presentation in the main group reduced by $65.8 \%$, and by $42.7 \%$ in the control group, correspondingly.

The level of general score expression according to the PANSS scale in the main group reduced by $67.1 \%$ and by $46.9 \%$ in the control group.

Assessment of social functioning in schizophrenia patients at the first stage of examination showed general behavioral dysfunction in the society: obvious - $24.2 \%$, serious - $26.5 \%$, and very serious - $28.1 \%$ dysfunction; disorders in fulfillment of the social roles in the society: 
obvious - $24.8 \%$, serious $-27.4 \%$, very serious $-28.6 \%$ dysfunction; disorders of the patient functioning in the hospital: no dysfunction - $2.4 \%$, minimum dysfunction - $10.9 \%$, obvious dysfunction - $27.1 \%$, serious - $33.5 \%$, very serious - 25,9\%; dysfunction of modifying factors of the patients (the patient's positive qualities, personal hazards, home atmosphere, outside support): no dysfunction - $3.4 \%$, minimum dysfunction $-13.1 \%$, obvious $-25.6 \%$, serious $-24.1 \%$, very serious $-34.2 \%$ of the examined patients.

\section{Conflict of interests}

There is no conflict of interests.

\section{RESULTS AND DISCUSSION}

The results of the assessment of the patients' positive attitude to the conducted therapy using the "Method of predicting the medicinal compliance in psychiatry" and TSQM allowed to find statistically reliable changes (Tables $1,2)$.

Table 1

Changes in self-assessment of the patients' satisfaction with the therapy using the TSQM methods before and after complex treatment (in points)

\begin{tabular}{|l|c|c|c|c|}
\hline \multicolumn{1}{|c|}{ Scales } & $\begin{array}{c}\text { Control } \\
\text { group }\end{array}$ & $\begin{array}{c}\text { Primary } \\
\text { condition }\end{array}$ & $\begin{array}{c}\text { After con- } \\
\text { ducted } \\
\text { psycho- } \\
\text { educational } \\
\text { influence }\end{array}$ & $\mathrm{P}$ \\
\hline $\begin{array}{l}\text { Therapy effi- } \\
\text { ciency }\end{array}$ & $49,1 \pm 1,9$ & $47.8 \pm 2.5$ & $76.4 \pm 0.3$ & $<0.001$ \\
\hline Convenience & $53,6 \pm 1,3$ & $52.1 \pm 2.5$ & $64.3 \pm 1.6$ & $<0.01$ \\
\hline $\begin{array}{l}\text { General satis- } \\
\text { faction with the } \\
\text { treatment }\end{array}$ & $43,7 \pm 2,1$ & $42.9 \pm 2.8$ & $54.5 \pm 1.1$ & $<0.01$ \\
\hline Side effects & $76,4 \pm 0,8$ & $77.9 \pm 2.0$ & $64.4 \pm 1.2$ & $<0.01$ \\
\hline
\end{tabular}

Assessment of the positive attitude towards the therapy in schizophrenia patients before and after complex treatment (in points)

\begin{tabular}{|l|c|c|c|c|}
\hline \multicolumn{1}{|c|}{ Scales } & $\begin{array}{c}\text { Control } \\
\text { group }\end{array}$ & $\begin{array}{c}\text { Primary } \\
\text { condition }\end{array}$ & $\begin{array}{c}\text { After conduct- } \\
\text { ed psycho- } \\
\text { educational } \\
\text { influence }\end{array}$ & $P$ \\
\hline $\begin{array}{l}\text { Total compli- } \\
\text { ance index }\end{array}$ & $31,2 \pm 0,9$ & $29.9 \pm 2.6$ & $38.9 \pm 0.7$ & $<0,001$ \\
\hline $\begin{array}{l}\text { Attitude to } \\
\text { medication }\end{array}$ & $17,1 \pm 1,4$ & $16.3 \pm 1.8$ & $22.4 \pm 0.7$ & $<0.01$ \\
\hline $\begin{array}{l}\text { Patient-related } \\
\text { factors }\end{array}$ & $7,6 \pm 0,4$ & $7.1 \pm 0.8$ & $9.2 \pm 0.6$ & $<0.05$ \\
\hline $\begin{array}{l}\text { Relatives- } \\
\text { related factors }\end{array}$ & $4,3 \pm 2,5$ & $4.3 \pm 0.3$ & $4.5 \pm 0.8$ & \\
\hline $\begin{array}{l}\text { Doctor-related } \\
\text { factors }\end{array}$ & $2,2 \pm 1,7$ & $2.3 \pm 0.3$ & $2.8 \pm 0.8$ & \\
\hline
\end{tabular}

During the work from the trialogue position the assessment of the schizophrenia patients' life quality was conducted (according to N.O. Maruta, 2004). With regard to all patients in the general life quality structure on the first stage of the examination, the following spheres were determined as the most problematic: socio-emotional support - 15.1\%; physical welfare and capability - $11.3 \%$; social and official support - 14.4\%; self-servicing and independence in actions - 10.1\%; self-realization - $7.9 \%$; interpersonal communication - 8.3\%; psychological, emotional welfare - 7.2\%; general life quality perception $11.6 \%$.

After psycho-educational measures the life quality in the main group according to all scales increased by $40.2 \%$ and by $27.7 \%$ in the control group.

According to the results of the follow-up supervision in the main group secondary to the conducted complex therapy with the use of psycho-educational intervention 82.2\% patients achieved the stable therapeutic effect, maintained during 2 years, in $11.1 \%$ the condition remained unchanged, and $6.7 \%$ showed the disease relapse. In the control group the condition improvement was observed only in $10 \%$ of patients, $48 \%$ were hospitalized due to relapse. The efficiency criteria included remission stability, hospitalization frequency, life quality, anxiety level, improvement of the mental condition.

\section{CONCLUSIONS}

Thus, according to the research results, complex approach in schizophrenia therapy, which included psychopharmacotherapy with the use of atypical antipsychotics in combination with the psycho-educational trainings, leads to the renovation of the social activity and successful resocialization of the patients. This, in its turn, testifies to the fact that psychological education not only increases the level of knowledge, improves the confidence in the fight against the disease, but also solves the problem of the patient's social reintegration. 


\section{REFERENCES}

1. Abramov, V.A., Zhigulina, I.V., Ryapolova, T.L. (2009). Psychosocialnaya reabilitacia bol'nyh shizofreniey [Psychosocial rehabilitation of patients with schizophrenia]. (Donetsk, Ukraine): Zdorov'a.

2. Anderson, C.A. (2000). Psychoeducational program for patients with schizophrenia. (London, Grate Britain): Aspen Publishers.

3. Anthony, W.A. (2008). Cognitive remediation and psychiatric rehabilitation. Journal of Psychiatry Rehab, 32, $87-88$.

4. Burns, T. (2007). Social functioning as an outcome measure in schizophrenia studies. Acta Psychiatrica Scandinavica, 116, 403 - 418.

5. Dammen, G, Maryta, N., Kozhyna, H., Mangubi, V. (2016). Femenologia I psihoterapia v psihiatrii [Phenomenology and Psychotherapy in Psychiatry]. (Kharkiv, Ukraine): FLP Timashev V.I.

6. Danilov, D.S., Tyulpin, Yu. (2010) Lechenie shizofrenii [Treatment of schizophrenia]. (Moscow, Russia): Medical News Agency.

7. Deci, E.L., Ryan, R.M. (2008) Facilitating optimal motivation and psychological well-being across life's domains. Canadian Psychology, 49, 14 - 23.

8. Kozhyna H., Korostiy, V. (2014) Psychoeducation in multiprofessional psychiatric care: Ukrainian experience, Abstracts book of DGPPN Congress, Berlin, Germany, 06-16

9. Kozhyna, H., Korostiy, V., Kryshtal, O., Kryshtal, V. (2014). The psycho-social rehabilitation of patients with schizophrenia, Abstracts book of XVI World Congress of Psychiatry, 6, 67, 232.

10. Kozhyna, H., Gaichuk, L., Samardakova, G. (2010) Rol' psychoobrazovatel'nyh program v okazanii psyhiatricheskoy pomoschi [The role of the psychoeducational program in Mental Health Care], Ukrainian News of psyhoneurology, №3 (64), 130.

11. Lincoln, T.M., Wilhelm, K., Nestoriuc, Y. (2007) Effectiveness of psychoeducation for relapse, symptoms, knowledge, adherence and functioning in psychotic disorders: a meta-analysis, Schizophrenia Research, 1-
3(96), 233.

12. Maryta, N.O., (2004) Ispol'zovanie integrativnogo pokazatela kachestva zizni $v$ diagnostike, terapii i reabilitacii bol'nyh shizofreniey [Using integrative index of quality of life in the diagnosis, treatment and rehabilitation of patients with schizophrenia], Archives of Psychiatry, 2 (37), 4 - 9.

13. McGurk, SR, Twamley, E.W., Sitzer, D.I., McHugo, G.J., Mueser, K.T. (2007) A meta-analysis of cognitive remediation in Schizophrenia, The American Journal of Psychiatry, 164(12), 1791-1802.[PMC free article] [PubMed]

14. Petersen, B., Toft, N.B., Christensen, Foldager, L., Munk-Jorgensen, L. (2008) Outcome of a psychotherapeutic program for patients with severe personality disorders, Nordic Journal of Psychiatry, 62, 450 - 456.

15. Ueoka, Y., Tomotake, M., Tanaka, T., Kaneda, Y., Taniguchi, K. (2011) Quality of life and cognitive dysfunction in people with schizophrenia, Progress in Neuropsychopharmacology and Biological Psychiatry, 35(1), $53-59$.

16. Shestopalova, L. (2007) Medyko-psyhologichni problemy suchasnogo likuval'no-reabilitaciynogo procesu [Medical and psychological problems of modern treatment and rehabilitation process], Ukrains'kyi Visnyk psychonevrolohii, 1 (50), P.249.

Received: 22-Oct. - 2016

Accepted: $\quad 20-$ Dec. - 2016 